\title{
Promotion Policy of Civil Servant Based on Meritrocracy Principle in Local Government of Indonesia
}

\author{
Tedi Sudrajat \\ Jenderal Soedirman University \\ tedi.unsoed@gmail.com
}

\author{
Siti Kunarti \\ Jenderal Soedirman University \\ siti_kunarti@yahoo.co.id
}

\author{
Sri Hartini \\ Jenderal Soedirman University \\ hartini.wy@gmail.com
}

\begin{abstract}
One of main issues in government promotion policy is by placing civil servants based on merit system which considering the promotion on how the qualification, competence, and performance are suitable with the position. Therefore, the first problem is the model of civil servant's promotion policy implemented today and any obstacle in implementing it. Then the second is model of an ideal policy to promote civil servants that based on meritocracy principle. Because of that, this article uses normative juridical approach and analyzing by normative qualitative method.From the analysis, the promotion policy of civil servants in Indonesia is known based on Law Number 5 Year 2014 on State Civil Apparatus. Particularly, the promotion authority for civil servant's promotion in Local government is delegated from President to the Local Head (District Head). Then it is the condition which lead the misuse of authority that affected to the elected officials based on spoil system. Because of what mentioned above, this article will discuss an ideal policy in promoting civil servants in Local Government based on meritocracy principle.
\end{abstract}

Keywords: civil servants, promotion, local government, meritocracy, policy

\section{INTRODUCTION}

In Indonesia, the issue of civil servant's promotion in the local government is not only studied from the aspects of administrativelaw but correlated with local government law. Based on Law No. 23 Year 2014 on Local government and Law No. 5 Year 2014 on State Civil Apparatus, there is an authority of the Head of Region to determine the appointment, transfer, and dismissal of civil servantsand the management of civil servants in government institutions. This wide authority needs to be anticipated, so that the issue of appointment in civil servant positions will still follow the principle of "merit system" not on "marriage system".

Although the Law on State Civil Apparatus has made the mechanism of check and balance by dividing authority for the Local Head as Local Officer of Civil Service Manager with the District Secretary as the Authorized Officer, but the mechanism is not enough,because there is an arrangement in the Local Government Law that creates a subordinate relationship pattern between the Head Local (superior) and District Secretary (subordinate).[2] This issue has been existed in several cases related to the abuse of authority of the Local Head in terms of promotion of civil servant within the local government, as well as bribery cases of local heads against the completion of civil servant positions in Klaten Regency. [1]

Conceptually, the implementation of civil servant's promotion is to fill vacant positions through a functional-structural relationship between the Head of Region and civil servants as the official duty officer. It can be identified as a constant relationship between the control function and domination. In this relation there will be always a problem, about "who controls who" and "who masters, leads and dominates". When the dominance of governance exists in one position, then the political and subjective interests will potentially be stronger. If it is correlated with the application of merit system based on competence, qualification, and performance, the promotion pattern of civil servant position will be very vulnerable with the inclusion of interests and intervention.

Until now, the object of completing position is a very strategic object because every regulation which concerning the relationship between the positions will be directly concerned with the government's efforts to create a professional staffing system and professionalism sources in position. Under these conditions, the pattern of civil servant position completion still has any obstacle particularly in terms of norms, standards, procedures and criteria.

This is an interesting issue when there are inter-law relationships that have implications of misusing the authority. Ideally, the relationship between the Local Head and the Civil Servant may be the basis for determining duties and authorities and to be a measure of whether rights and obligations are carried out properly or there is a confounding and transcending authority or acting arbitrarily. Conversely, rights and obligations may allow officials or stakeholders to take actions, either legal action or certain concrete actions (rechten feitelijkehandelingen). Then for everything that is not manifesting in a concrete form of action, will not be accountable. It is the legal concept which leads to the 
search of policies to anticipate the official relationship in the civil servant's relationship based on merit system.Based on those condition, this paper will explore First, the current policy model of civil servant promotion and what are the constraints in the implementation; and second, the ideal policy model for the promotion of civil servant positions based on meritocracy principles.

\section{METHOD}

This article uses a normative juridical approach. This normative approach focused on legal synchronization either vertically or horizontally. The problem is solved by using a statute approach, analytical approach and conceptual approach vertically and horizontally by emphasizing on the syllogistic process of thinking, departing from the major premise, bumping with a minor premise that produce conclusion. Then the analysis is using normative analysis qualitative by using 2 models of interpretation, that are grammatical interpretation and systemic interpretation.

\section{RESULT}

\section{Model of Current Civil Servants Promotion Policies and Constraints in the Implementation}

In the context of personnel management, promotion of civil servant positions is part of the government positions completion process. According to Logemann, there are many methods that can be used in completing the positions, including inheritance, appointment, election, outreach by office (in the combined position held today). Logemann adds that in any differences of position completion methods is actually there are only two choices; either completing the position by hanging on the agreement of the people or not dependent on the will of the people. [3] According to Bagir Manan, based on the criteria of accountability, the positions completion can be divided into three, First, completing the position by election; Second, completing the position by appointment; and Third, completing the positions that also contains the appointment and election (which serves as a statement of support).[4]

In the executive domain, every employee is attached to a position because they are recruited based on needs to perform the tasks and functions that exist within the organization. According to Wursanto, position relates to a series of work to be performed and requirements to perform the tasks and relates to the condition of environment in which the work is performed. Positions contain duties, responsibilities, human abilities, and performance standards.[5] Based on the concept, duties in office are correlated with the authorities in performing administrative functions. In this connection, positions are authorized to perform government actions, one of them is promoting a position. In delegative consept, the position of Local Head is granted authority as delegated in Article 1 Number 14 of State Civil Apparatus Law that:
Personnel Officer is an officer who has the authority to determine the appointment, transfer and dismissal of civil servants, and to guide the Management of civil servants in a governmental institution in accordance with the provisions of legislation.

Then the position of the District Secretary is given the authority as set out in Article 1 paragraph 13 of the State Civil Apparatus Law that the Authorized Officer is an officer that has the authority to implement the appointment, transfer, and dismissal the process of civil servants in accordance with the provisions of the law.

Observing the normative aspect (the substantial and structural) of Local Head position and Secretary of district, there is sub-ordinate relationship pattern within. In employment system, sub-ordinate relationship pattern is based on the relation of public agency pattern (openbaredienstbetrekking), as it requires employees to obey the appointment in some sort of a particular position that causes the employees admit their appointment in a certain position that has been determined by the Government unconditionally. Contradictory, the Government has the rights to appoint an employee in a particular position without the existence of adjustment of wills of those that has been concerned. [6]The implication of Public Agency is the realization of a sub-ordinate relationships between subordinates and superiors. According to Buys, Public Agency relationship is based on Contract Suigeneris which requires civil servants should be loyal and obedient. From Buy opinion, it concludes that being civil servant, they cannot get their rights fully.

Based on public agency concept, every civil servant include secretary of district are obliged to obey the regulation by government, including hierarchical relationships in the Governance structure. According to this pattern, then Local Head position served as supervisor to Secretary of District performance. Besides, Local Head position is the party that determine the strategic decisions in the framework of the Government policy organization. Article 213on Local Government Law stated in conducting their job, Secretary of District has responsibility to Local Head. In legal context, the analogy of the sub-ordinate relationship in the Office can be synchronized by the relationship between the norms that regulate the formation of other norms containing elements of "super ordinate and "subordinate". Known as the hierarchy, the inferior should obey the superior. [7]Therefore, then the position of supervisor is supervising and control policies that will be issued, including in terms of setting a profile that fills the vacant position.

Observing the sub-ordinate (legal position between Local Head and Secretary of District), it will creates dualism of authority that cause legal authority implication of Local Head. In those relationship, the sub-ordinate position which say Local Head is a leader of Secretary of District. It means, Local Head tend to be dominant to choose the official authority use. 
According to the sub-ordinate condition, the appointment of civil servant will influenced by subjective relationship which are First, political relationship and Second, non-political relationship which is nepotism. From these relationships, it can be seen that the party supporter of Local Head deserves to enjoy all the facilities that are attached to the Office or this relationship is known as spoil system. According to James H Svara, empirically the interactions of elected official and administrators have the following characteristics that have been observed:

1. Elected officials and administrators maintain distinct perspective based on their unique values and the difference in their formal positions.

2. Official have partially overlapping functions as elected officials provide political oversight of administration and administrators are involved in policy making.There is interdependency and reciprocal influence between elected officials and administrators. [8]

Through those relations, there is justification in civil servant promotion still affected by patrimonial and patriarchy leadership style. Characteristics of patrimonial bureaucracy are First, officials screened on the basis of personal criteria; Second, the Office is seen as a source of wealth and profit; Third, officials control either the functions of political or administrative and Forth, any action directed by the personal and politics relationship. [9]

\section{Ideal Policy Model in the Promotion of Civil servants Position Based on Principal of Meritocracy}

Based on the mechanism of democracy and how to get authority, it is clear that Local Head is a local leader and dominant. For that condition, limiting Local Head's authority as Local Finance Manager is a must, so the objectivity in Civil servants' position promotion would be controlled. Possible efforts to limit the authoarityand creating healthy working patterns of government are:

1. Strengthening legal substance in terms of implementation, supervision, and law responsibility of government's action in misusing their authority.

2. Creating commitment of the government's officials to be synergy with government's policy which is oriented on the capacity and capability enhancement in running the nation.

3. Orienting on the quality of human resources apparatus. "Changing public service, changing public servant?" is what last sub part of Andrew governance system (e-gov). Technology becomes an important factor on the enhancement of supervision and law enforcement. The use of technology is going to force elite commitment, system and government's apparatus to change. In contrast, the use of technology relies highly on the apparatus and officials in the region. It is because their quality and commitment, or even the highest technology means nothing without their support.
4. Creating superior culture in government. This refers to the effort to create character on building goodsynergy environment. Neo dan Chen in the book Dynamic Governance: Embedding Culture Capabilities and Change in Singapura (2007) stated that dynamic institution is characterized as the existence of new ideas, fresh perception, sustainable up-grading, fast actions, flexible adaptation, and creative innovation. This kind of institution is going to create the institution that always learn about effective and fast policy and never-ending changes.

It can be inferred from those 5 (five) working pattern that pre-requirements in form of law, commitment, orientation on human resources apparatus quality and the using of technology is needed in creating proportional authority relation. If we correlate with nowadays condition, authority to assign officials candidate is Head District's authority as the Local Finance Manager, but their authority must be limited. The authority to value, evaluate, and recommend the names of official's candidate, it is fully given to the system through assessment center. It means that Local Head is given the authority based on his portion, which is assigning without interfering the result of official's candidate's score.

\section{CONCLUSION}

The concept which is supposed to be developed are First, the pattern of relation between Local Head as the Local Finance Manager and District Secretary as the authorized officials limited by Norms, Standard, Procedure, and Criteria through the supervision and responsibility of administrative law and strengthening system with technological basis;and Second, the process of Civil servants' steps in the promotion of their position is led to be able developing the potential of internal human resources.

\section{REFERENCES}

[1] https://www.cnnindonesia.com/ nasional/ 20170227200718-12-196608/kasus-jual-belijabatan-pns-klaten-dititipkan-ke-lp-semarang, 28 February 2017.

[2] Sudrajat, Tedi and Muttaqin, Zainal, "Reconstruction The Patterns Of Authority Relations Between Head Of Local Government and Secretary of Local Government On Promotion Of Civil Servants", Jurnal Dinamika Hukum, Vol. 16 No. 2, 2016

[3] Logemann, J.H.A, "Over de Theori Van Een Stelling Staatsrecht", Universitaire Pers Leiden, 1948

[4] Manan, Bagir, "Teori dan Politik Konstitusi", UII Press, 2003

[5] Wursanto, I.G., "Manajemen Kepegawaian 1", Kanisius, 1991

[6] Marbun,F. andMD,Mahfud, "Pokok-Pokok Hukum Administrasi Negara", Liberty, 1987 
[7] Soeroso, "Pengantar Ilmu Hukum", Sinar Grafika, 2005

[8] Svara, James H, "Complexity in PoliticalAdministrative Relations and The Limits of The Dichotomy Concept", Journal of Administrative, Vol. 28 No. 1, 2006
[9] Ramli, Lili, "Masalah Reformasi Birokrasi", Jurnal Kebijakan dan Manajemen PNS, Vol. 11 No. 2, 2008

[10] Gray, Andrew, "Government and Administration: Public Service and Public Servants"Parliamentary Affairs, Vol. 58 No.2, 2005 